\title{
COMPARATIVE STUDIES ON THE HALF-LIFE OF I I31-LABELED ALBUMINS AND NONRADIOACTIVE HUMAN SERUM ALBUMIN IN A CASE OF ANALBUMINEMIA
}

\author{
By HERMANN BENNHOLD AND EKKEHARD KALLEE \\ (From the Medizinische Universitätsklinik, Tübingen, Germany)
}

(Submitted for publication February 20, 1958; accepted January 8, 1959)

Hypoalbuminemia occurs frequently in the course of wasting disease but never progresses to a condition of complete analbuminemia. The latter, in fact, is unknown in pathology. Analbuminemia, however, has been described as a benign congenital syndrome occurring in siblings (1-3). The absence of serious pathological changes in these two cases is striking and makes it appear likely that this form of benign analbuminemia belongs to the realm of congenital aberration of protein metabolism.

The absence of circulating albumin creates a unique basal condition which makes it easy to follow the fate of infused albumin by more than one method. It was decided, therefore, to study the rate of disappearance of albumin in one of the siblings (a female) and to use for this purpose both $\mathrm{I}^{131}$-labeled albumin and a commercial human albumin. The rate of disappearance of the former was obtained by measuring the decay of radioactivity in the usual manner and of the latter by means of paper electrophoresis and immunological tests.

\section{METHODS AND MATERIALS}

1. Infusions of human serum albumin. During the three months preceding the first injection of human serum albumin in 1953, numerous routine clinical and biochemical tests were made (1-5). On June 10, 1953, 50 $\mathrm{Gm}$. of commercial human serum albumin (Behringwerke, Marburg) ${ }^{1}$ in $250 \mathrm{ml}$. of saline solution was injected intravenously. On the day of the injection hemoglobin was 84 per cent (or $13.5 \mathrm{Gm}$. per $100 \mathrm{ml}$ ) and hematocrit values were 34 to 38 per cent. Preliminary intracutaneous tests with albumin had shown no signs of an allergic reaction. At intervals after the intravenous injection of albumin, further blood samples were taken and the tests repeated.

Further infusions of human serum albumin were made on March 30, 1954 (202 Gm. within 11 days), on Feb.

1 This albumin was prepared without crystallization and was pasteurized in the usual manner.
25, 1955 (150 Gm., 7 days), on Jan. 20, 1956 (200 Gm., 9 days), and on May 12 and 13, 1957 (205 Gm., 11 and 4 hours). All these infusions were tolerated well.

2. $I^{131}$-albumin. a) To $10 \mathrm{mc}$. of "carrier-free" $\mathrm{I}^{131}$ (containing 10 to $20 \mu \mathrm{g}$. of $\mathrm{NaI}$ ) was added $0.015 \mathrm{ml}$. of a $\mathrm{KIO}_{3}$ solution containing $600 \mu \mathrm{g}$. of $\mathrm{KIO}_{3}$ per ml. After acidifying this mixture with $0.1 \mathrm{ml}$. of $2 \mathrm{~N} \mathrm{H}_{2} \mathrm{SO}_{4}$, the liberated $\mathrm{I}^{131}{ }_{2}$ was taken up in $0.25 \mathrm{ml}$. $\mathrm{CCl}_{4}$, and the aqueous phase was once more extracted with $0.2 \mathrm{ml}$. of $\mathrm{CCl}_{4}$. This solution of $\mathrm{I}^{131}$ was added to $30 \mathrm{mg}$. of human serum albumin dissolved in $0.3 \mathrm{ml}$. of 1.25 per cent $\mathrm{Na}_{2} \mathrm{CO}_{3}(6)$. The layers of both $\mathrm{CCl}_{4}$ and albumin solution were gently mixed by slowly rotating the glassstoppered test tube for five minutes at room temperature until the pink color of the $\mathrm{CCl}_{*}$ layer had disappeared. The iodinated albumin solution was allowed to stand 60 more minutes; it was then carefully brought to approximate neutrality by adding $0.1 \mathrm{ml}$. of $\mathrm{N}$-acetic acid. Meanwhile, a sterile Seitz microfilter was desorbed (i.e., inactivated) by use of $1.0 \mathrm{ml}$. of the analbuminemic subject's serum. Then the $\mathrm{I}^{131}$-albumin solution was filtered and the filter twice washed with serum portions of 0.5 $\mathrm{ml}$. each. The mixture of $\mathrm{I}^{131}$-albumin and serum was transferred to a dialysis bag and dialyzed six days against frequently changed $200 \mathrm{ml}$. portions of Ringer solution; the first dialyzing solution had 0.1 per cent KI added to it. At the end of the dialysis period, radioautograms of paper electrophoresis strips showed no trace of iodide, i.e., less than 0.1 per cent of the protein radioactivity, nor did the protein solution contain any traces of $\mathrm{I}^{131}$-tagged globulins. The total yield was 1.25 mc., i.e., 12.5 per cent of the originally used $10 \mathrm{mc}$. of $\mathrm{NaI}^{131}$.

This $\mathrm{I}^{131}$-albumin was used for the first experiment on Feb. 22, 1954.

b) For the second experiment on May 10, 1957, we used the commercially produced $\mathrm{I}^{131}$-labeled albumin, RISA ${ }^{\circledR}$ (Abbott).

c) On July 18, 1958, jet iodinated $\mathrm{I}^{131}$-albumin was kindly prepared by Dr. A. S. McFarlane by the following procedure. To $40 \mathrm{mg}$. recrystallized, pasteurized human albumin (Behringwerke, Marburg) in $0.8 \mathrm{ml}$. of $0.05 \mathrm{M}$ glycine buffer, $\mathrm{pH} 4.5$, was added free inactive iodine prepared by slightly acidifying a balanced mixture of sodium iodide and iodate. This was added dropwise until the color of free iodine persisted, indicating that the free sulphydryl groups had been oxidized. Iodide formed in this reaction and excess iodine were removed by passing the solution through a column $(25 \times 7 \mathrm{~mm}$. $)$ of Deacidite FF resin (Permutit Co. London, Ltd.) in the 
chloride form. The $\mathrm{pH}$ of the effluent was adjusted to 9.0 by adding $\mathrm{N} \mathrm{NaOH}$ and the solution taken up in a capillary pipette.

The labeling solution was now prepared by taking 0.30 $\mathrm{ml}$. of a stock aqueous solution of iodine monochloride containing $0.42 \mathrm{mg}$. iodine per $\mathrm{ml} .0 .01 \mathrm{M} \mathrm{HCl}$ and $\mathrm{M}$ $\mathrm{NaCl}$ and injecting into it $0.7 \mathrm{ml}$. of $0.05 \mathrm{M}$ glycine buffer, $\mathrm{pH}$ 9.0. This colorless solution, which effectively contains all its iodine as hypoiodite ion, now had $2.0 \mathrm{mc}$. of carrier-free $\mathrm{I}^{131}$ added to it. The latter solution, which must be free of reducing agent, is obtained by condensing $\mathrm{I}_{2}^{181}$. vapor into $0.01 \mathrm{~N} \mathrm{NaOH}$ and is obtainable from the Radiochemical Centre, Amersham.

The mixture was taken up in another capillary pipette and the contents of both pipettes discharged under pressure so that the fluid jets impinged on a common surface where turbulent mixing occurred. The mixture was passed through a second Deacidite column and the effluent, containing $1.2 \mathrm{mc}$. of iodine distributed at a mean level of 0.80 atom per molecule of albumin, then received $200 \mathrm{mg}$. of unlabeled albumin to reduce radiation damage during storage. Sterile filtration followed through a Seitz pad and an aliquot of the filtrate was used for injection. One and four-tenths per cent of the activity in it was nonprotein-bound as measured by trichloroacetic acid precipitation.

3) Counting techniques. a) In 1954, we counted the serum radioactivities in a gas-filled Geiger fluid-counter tube (Zentralwerkstatt, Göttingen). In each experiment we counted at least 10,000 impulses. The counter tube had a sensitivity of $11,000 \mathrm{cpm}$ per $\mu \mathrm{c}$. in a volume of $10 \mathrm{ml}$. and above a background of 28 to $30 \mathrm{cpm}$.

b) In 1957 and 1958, measurements were made in a welltype scintillation counter (Frieseke \& Hoepfner, ErlangenBruck). This has a sensitivity of $750,000 \mathrm{cpm}$ per $\mu \mathrm{c}$. $\mathrm{I}^{131}$ in $3 \mathrm{ml}$, above a background of $200 \mathrm{cpm}$. We counted the $3 \mathrm{ml}$. samples in Fiolax ${ }^{\circledR}$ test tubes (Schott \& Gen., Mainz).

4) Immunological and electrophoretic determinations. The immunological estimations of the albumin content of the patient's serum in 1953-54 were performed by Dr. F. Lohss after the method of Heidelberger and Kendall (7) using a rabbit antiserum with a high specificity against human albumin. Until 1956, the routine paper electrophoresis in this clinic was done by Dr. E. Roth, later by Dr. G. Scheurlen. Protein was estimated by the

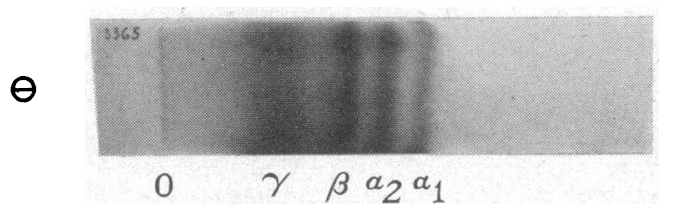

Fig. 1 A. Paper Electrophoresis Strip of the ANalbuminemic Subject's Serum on April 10, 1953, Prior to the First Infusion of Human Albumin

Seven-thousandths $\mathrm{ml}$. of serum was put onto the start line. No traces of albumin are visible on this strip $\bigcirc$ indicates start line; $\oplus$, anode; and $\ominus$, cathode.
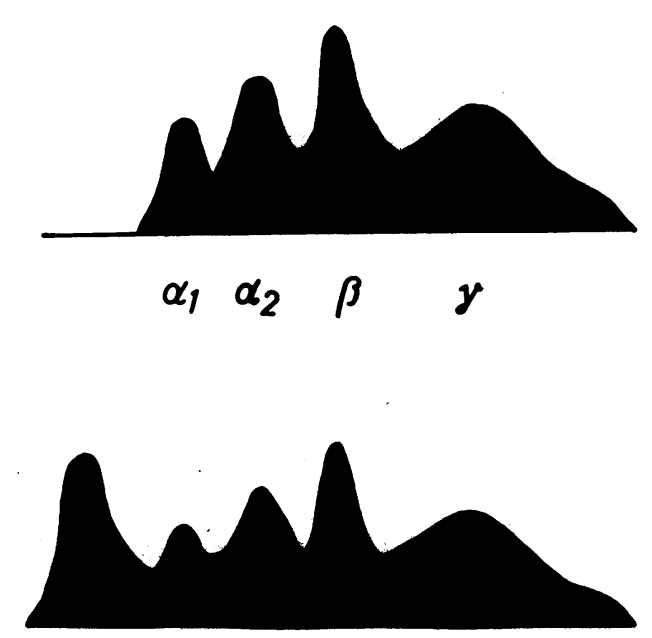

\section{alb. $\alpha_{1} \alpha_{2} \quad \beta \quad \gamma$}

Fig. 1 B. Paper Electropherograms of the Serum of the Same Subject Before (Top) and After (Bottom) the First Injection of $50 \mathrm{Gm}$. of Albumin on JUNE 11, 1953

$\mathrm{CuSO}_{4}$ density method (8), and by Kjeldahl nitrogen determinations. Paper electrophoresis was carried out using the Grassmann apparatus with sodium veronalacetate buffer, $\mathrm{pH} 8.5, \mu=0.1$, employing a current of 4 V. per $\mathrm{cm}$. The Whatman No. 1 paper strips were stained with amidoschwarz 10B (Bayer, Leverkusen). The stained strips were soaked in bromonaphthalene-paraffin and then scanned in a special colorimeter (Zeiss, Oberkochen); the curves were evaluated planimetrically.

\section{Brief summary of the clinical condition (1-5)}

The female analbuminemic subject, a peasant's daughter who was born in 1922, came into the clinic with edema in her ankles. She was sent by her physician for investigation of a high blood sedimentation rate (between 42/68 and 95/104 mm. Westergren) and a hypotension of $90 / 55 \mathrm{~mm}$. $\mathrm{Hg}$. The edema appeared regularly before and during menstruation. Other clinical and biochemical data were: blood calcium, 8.2 to $8.5 \mathrm{mg}$. per cent; TakataAra, thymol turbidity, Weltmann's $\mathrm{CaCl}_{2}$ coagulation, and $\mathrm{CuSO}_{4}$ reactions strongly positive. Volhard's diuresis test (water shock) showed an excessive diuresis, but normal concentration values. The cholesterol, total lipoid, hexosamine, protein-bound hexose, and choline esterase values in the serum were elevated. Both colloid osmotic and capillary pressures were low. Normal serum values were found for potassium, phosphorus, urea, uric acid, nonprotein nitrogen, creatinine, bilirubin, chlorides, alkaline phosphatase and prothrombin. Normal values were also found in some liver function tests, i.e., galactose, "Testacid®," and bromosulfalein. Some renal clearance tests showed pathological changes, e.g., p-aminohippuric acid and inulin.

Total serum protein was $4.6 \mathrm{Gm}$. per $100 \mathrm{ml}$; the relative composition of the globulins averaged as follows: 


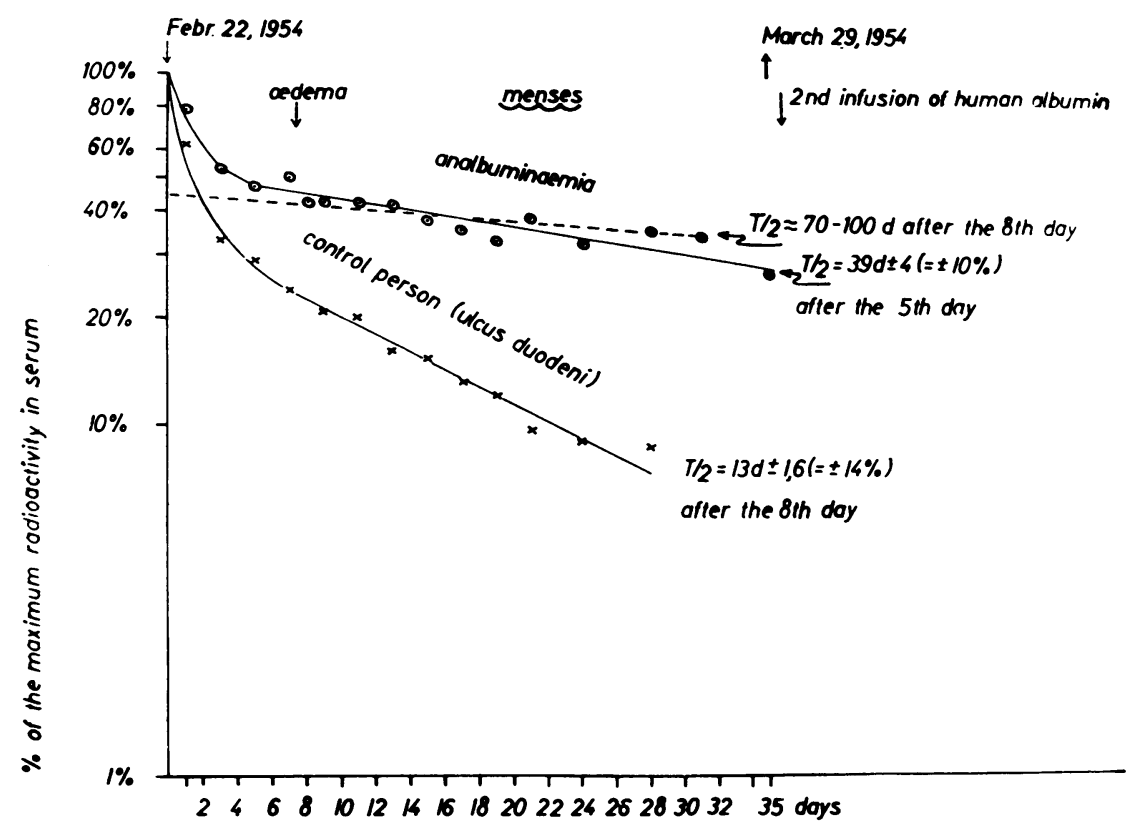

Fig. 2. Comparison of the Disappearance from Blood Stream of a Laboratory Preparation of I $^{131}$-Albumin in a Case of Analbuminemia ( $\bigcirc-O$ ) and in a ConTROL SUbJect $(X-X)$

Ordinate: serum radioactivity in per cent of the maximum serum radioactivity 15 minutes after the injection. Abscissa: time elapsed after the injection.

$\alpha_{1}, 7.4$ per cent ; $\alpha_{2}, 19.7$ per cent ; $\beta, 32.1$ per cent ; $\gamma, 40.8$ per cent (Figure 1). These values varied within the limits of methodological error. No albumin could be detected by use of both free and paper electrophoresis, ultracentrifuge, or immunological experiments within the limits of the specificity of these methods, i.c., less than 1 per cent of the total serum protein.

Evans blue disappeared at an almost normal rate during the first two hours, but afterwards more rapidly. Congo red disappeared at the high rate of 70 per cent from the blood stream within one hour as compared with 30 per cent in normal subjects (9). Such extremely high rates are usually encountered in amyloidosis only. In this instance, however, the rapid disappearance is caused by the deficiency of albumin to which congo red is normally bound. This is a striking example of how the presence of albumin vehicles (32) normally affects the disappearance rates of some substances which are circulating in the blood stream.

The family tree bears several intermarriages (3). We conclude from it that complete deficiency of albumin is a highly recessive hereditary trait.

The exact data are contained in earlier papers (1-4, $10-13$ ), or will be published in due course (5).

\section{RESULTS}

\section{I) Preliminary experiments}

The analbuminemic subject was injected intravenously with $50 \mathrm{Gm}$. of noncrystallized human se- rum albumin for the first time on June 10, 1953. when she was 31 years old and weighed $73.3 \mathrm{Kg}$. This first injection was done within half an hour. Two hundred and twelve days later, on Feb. 22, 1954, $30 \mathrm{mg}$. of $\mathrm{I}^{131}$-tagged albumin containing 325 $\mu c$. of $\mathrm{I}^{131}$ was injected. On this day, her blood still contained about $0.15 \mathrm{Gm}$. per cent albumin from the first injection, and hemoglobin was 80 per cent (or $12.8 \mathrm{Gm}$. per $100 \mathrm{ml}$.). The plasma volume was about $3.6 \mathrm{~L}$. as determined with $\mathrm{I}^{131}$ albumin. Total protein nitrogen was $5.1 \mathrm{Gm}$. per $100 \mathrm{ml}$.

During the first five to eight days after the injection of $\mathrm{I}^{131}$-albumin, the radioactivity per milliliter of serum decreased more rapidly than it did subsequently (Figure 2). This initial high rate of decline is in conformity with the literature and has been ascribed mainly to establishment of an equilibrium between intra- and extravascular spaces (14-16). After the first five to eight days, the slope of the curve changed to an approximately straight line. The points of this line can be connected in such a way as to yield half-life figures of either 35 to 43 days (1-3) or up to as much as 70 to 100 days. No correction was made for a loss of 


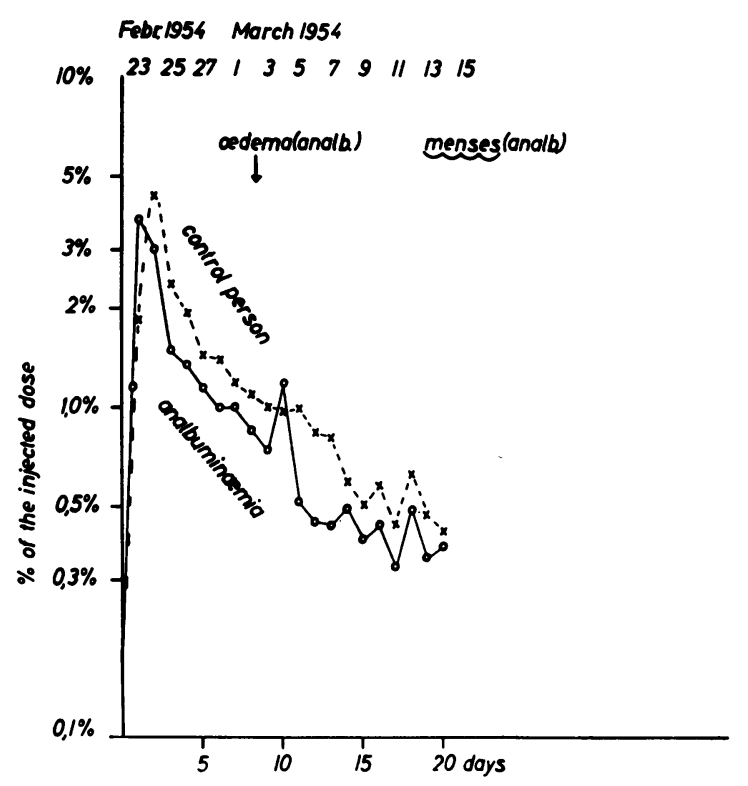

Fig. 3. Daily Urinary Excretion Rates of RaDioActivity After the First Injection of I $^{131}$ Albumin

The TCA-precipitable radioactivities were less than 1 per cent of the total radioactivities excreted in both cases. Ordinate: per cent of the injected total radioactivity. Abscissa: time. Analbuminemic subject $(\mathrm{O}-\mathrm{O})$; control $(X---X)$.

radioactivity of about 5 per cent due to withdrawal of blood samples. The half-life of the same preparation of $\mathrm{I}^{131}$-albumin in a control subject averaged 13 days.

During the first 20 days after the injection of $\mathrm{I}^{131}$-albumin, the analbuminemic subject excreted only about 20 per cent of the injected radioactivity in the urine (Figure 3 ). For want of a sufficiently sensitive Geiger counter, we were unable to measure exactly the radioactivity of the thyroid. But from some isolated measurements and from data given in the literature (17) we may assume that the uptake of $\mathrm{I}^{131}$ by the thyroid is negligibly low (not exceeding 5 to 10 per cent).

After the injection of commercial human serum albumin nine months earlier, the half-life of this nonradioactive albumin was also about 70 (60 to 80 ) days, as determined by paper electrophoresis and immunological methods (Figure 4). Thus, it appeared that the half-life of albumin in this subject is much longer than in normals, and the values given by the two different methods are similar.

\section{II) Second series}

The determination of the half-life of $\mathrm{I}^{131}$-albumin was repeated in the subject between May 10 and June 30,1957 . This time the subject's serum contained almost indetectable traces of albumin from former infusions; total serum protein was $5.0 \mathrm{Gm}$. per $100 \mathrm{ml}$. ( $\mathrm{CuSO}_{4}$ method); hemoglobin, 94 per cent (or $15.0 \mathrm{Gm}$. per $100 \mathrm{ml}$.). Hematocrit values averaged 42 per cent. Only small amounts of blood ( 6 to $10 \mathrm{ml}$. samples) were taken in comparatively long time intervals. Instead of a laboratory-made preparation of $\mathrm{I}^{\mathbf{1 3 1}}$ albumin, we injected $6 \mathrm{mg}$. of the commercial $\mathrm{I}^{131}$-labeled albumin, RISA ${ }^{\circledR}$ (Abbott), containing $60 \mu \mathrm{c}$. of $\mathrm{I}^{131}$. This time, plasma volume was $3.0 \mathrm{~L}$. We were now able to follow the disappearance of radioactivity for 51 days by using a well-type scintillation counter (Figure 5). The paper electrophoresis strips were now evaluated, taking due care to exclude nonmigrating paper-bound and denatured protein $(18,19)$ when present (in traces).

On the second and third days after the injection of RISA ${ }^{\circledR}, 205 \mathrm{Gm}$. of nonradioactive human serum albumin ${ }^{2}$ was infused into the subject, 175 $\mathrm{Gm}$. within 11 hours. As a result of this main infusion of $175 \mathrm{Gm}$. of albumin dissolved in $1.2 \mathrm{~L}$. of saline solution and $2.3 \mathrm{~L}$. of 5 per cent glucose solution, the plasma volume increased during the day, causing a drop in radioactivity from 45 to 32 per cent of the value found 10 minutes after the injection (Figure 6). This fall in plasma radioactivity is equivalent to an increase of plasma volume from approximately 3.0 to about $4.2 \mathrm{~L}$. During both infusions, and during the night following the main infusion, the subject excreted a total of 5.9 L. of urine within 48 hours. After the main infusion the plasma radioactivity rose overnight to 37 per cent, this value again lying close to the slope of the curve of the initial disappearance, where one would have expected it to lie had no additional albumin been infused (Figure 6). The body weight remained unchanged at $69.5 \mathrm{Kg}$. These findings mean that the main part of the original plasma volume had been restored overnight.

$30 \mathrm{Gm}$. of albumin had been infused within four hours on the day before the main infusion

${ }^{2}$ Lots No. $1118 \mathrm{n}$ and 386 (Behringwerke). These lots had been manufactured on Nov. 1, 1956, and Dec. 12, 1952, respectively, and had not been crystallized. 


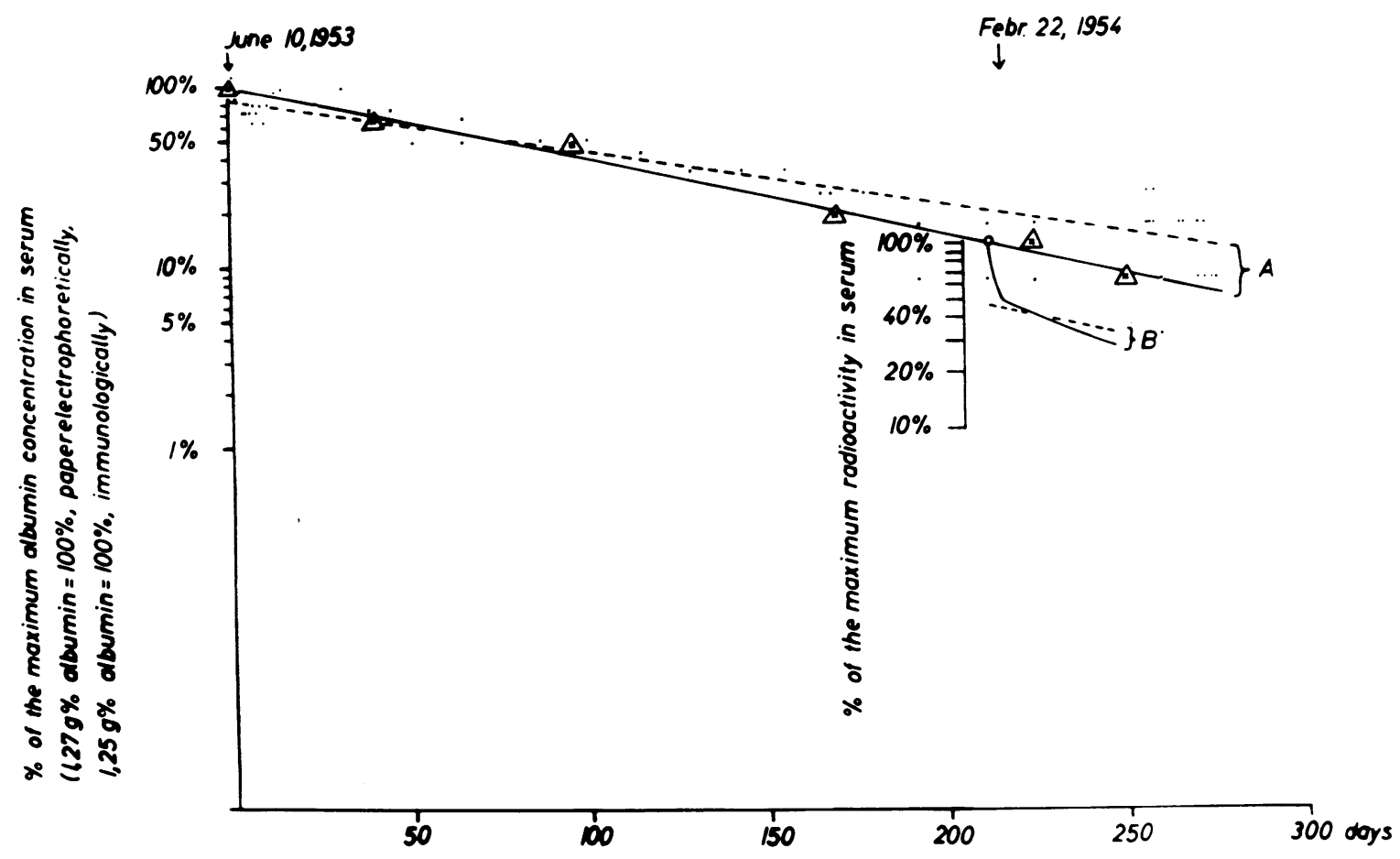

Fig. 4. Half-Life Curves of Unlabeled Human Serum Albumin (Straight lines, A) After the First Injection of I $^{131}$ Albumin into the Analbuminemic Subject

.$-\ldots$ indicates paper electrophoretic values; $\Delta-\triangle$ immunological values.

The auxiliary ordinate on the right is for the $\mathrm{I}^{131}$-albumin (B) and is drawn in the same scale as the main ordinate. The $B$ curves are identical with the upper two curves in Figure 2, but with the scale of the abscissa reduced five times. For the original points of Curve $B$ and the manner in which the two seemingly different lines can be drawn, see Figure 2.

Half life values of (A) nonradioactive albumin are $70 \pm 10$ days (solid line), or 90 to 110 days (broken line); (B) $\mathrm{I}^{131}$-albumin, $39 \pm 4$ days (solid line), or 70 to 100 days (broken line).

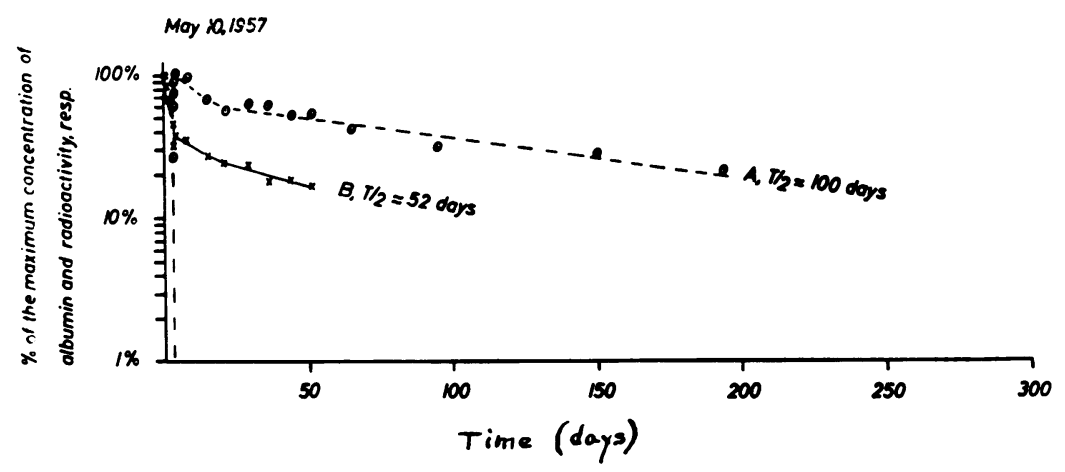

Fig. 5. Half-Life Curve of Human Serum Albumin ( $\bigcirc-O$ ) After the Infusion of $205 \mathrm{Gm}$. $(30+175 \mathrm{Gm}$.) of Nonlabeled Albumin

Two and ninety-five one-hundredths $\mathrm{Gm}$. per cent albumin in the serum equals 100 per cent in Curve A ( $O-O)$. The half-life curve, $B(X-X)$, after the injection of $6 \mathrm{mg}$. of $\mathrm{I}^{131}$-albumin (RISA ${ }^{\circledR}$ ) containing $60 \mu \mathrm{c}$. of $\mathrm{I}^{131}$ is also plotted. Note the sudden drop and rise of radioactivity following the infusion of serum albumin ( $c f$. Figure 6).

This was the fifth of a series of infusions in the course of four vears. 


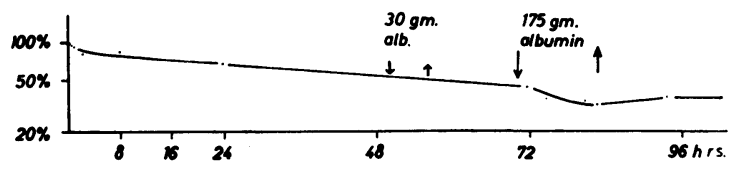

Fig. 6. Disappearance from Blood Stream of I $^{131}$ Albumin (RISA®) During the First Four Days After InJection

This curve is the same as Curve $B$ in Figure 5, except that the abscissa is drawn on a much wider scale. The arrows indicate the beginning and end of the additional infusions of 30 and $175 \mathrm{Gm}$., respectively, of nonradioactive albumin. Note the relatively sudden changes of plasma volume within a few hours.

(Figure 6). Compared with the $175 \mathrm{Gm}$. which was infused during the main infusion, the effect of this $30 \mathrm{Gm}$. of albumin on the plasma volume may be neglected.

Whereas the curve of disappearance of infused albumin in Figure 5 shows only a slight initial fall in the concentration of albumin, it is necessary to emphasize that this may arise from the artificial nature of the 100 per cent origin. Because this large amount of albumin was infused slowly over 11 hours and was associated with transcapillary migrations of water and of protein of an unpredictable nature, the starting albumin level of 2.95
Gm. per $100 \mathrm{ml}$. has no absolute significance. The absence of a sharp initial fall in plasma albumin concentration in this curve and in the ones in Figures 4 and 8 should not be taken to mean that this analbuminemic subject has an abnormally small amount of extravascular fluid. Indeed, when $\mathrm{I}^{131}$-albumin was injected instantaneously in tracer amounts, the rapid initial fall in plasma radioactivity suggested that the subject had a substantial extravascular fluid space available to albumin.

\section{III) Third series}

In order to decide definitely upon the questions arising from the differences which we had found in the first two experiments, we arranged a third experiment in co-operation with Drs. A. S. McFarlane, C. M. E. Matthews, T. Freeman (National Institute for Medical Research, London) and Prof. H. E. Schultze (Behringwerke, Marburg). For this purpose, the Behringwerke prepared a special lot of highly purified human albumin to which no preservative had been added. A sample of this albumin was jet-iodinated by Dr. McFarlane on July 18, 1958.

On July 20, 1958, the analbuminemic subject

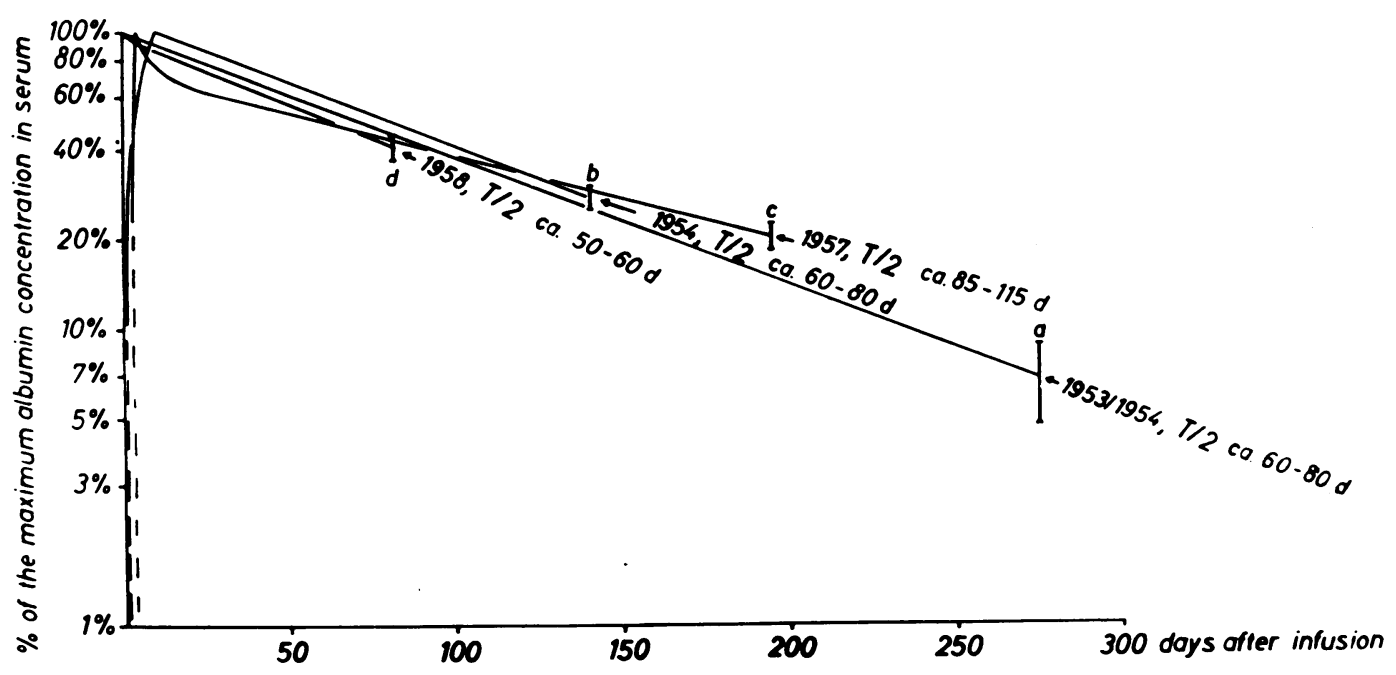

Fig. 7. Summary of Different Half-Life Curves Obtained from Experiments with Unlabeled Human Albumins in the Analbuminemic Subject Between 1953 and 1958

The perpendicular bars indicate the approximate mean error of the paper electrophoretic determinations. $a, b$ and $c$ : uncrystallized human albumins to which mercury-containing preservatives were added; $d$ : crystallized human albumin without preservative (first part of the preliminary observation period: only 89 days).

It is evident that these arbitrary half-life values are overlapping and, therefore, do not differ significantly from one another. 


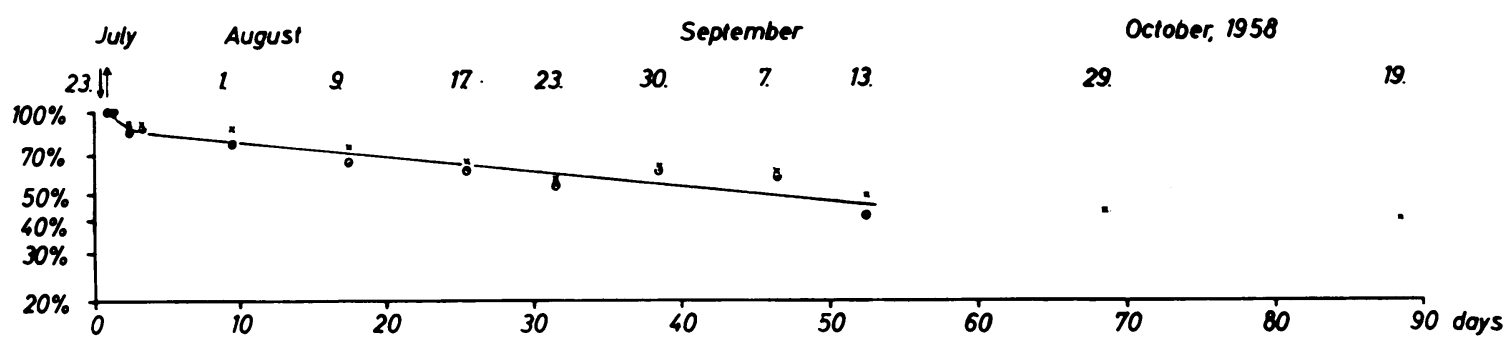

Fig. 8. Half-Life Curve of Both Nonlabeled Albumin $(\times-\times)$ and Jet-Iodinated ${ }^{131}$-Albumin $(\odot-\odot)$ After the Infusion of a Mixture of Both Albumin Preparations Within Nine Hours

Ordinate: per cent of the maximum concentration of human serum albumin $(2.63 \mathrm{Gm}$. per $100 \mathrm{ml}$.) and radioactivity, respectively. Abscissa: time, in days. Arrows indicate the beginning and end of the infusion of $145 \mathrm{Gm}$. of human serum albumin (Behringwerke) containing $68.5 \mu \mathrm{c}$. of jet-iodinated $\mathrm{I}^{131}$-albumin.

The half-life (about 50 to 60 days) and initial disappearance of both preparations are practically identical.

came again to the hospital with declining edema which had almost disappeared from her ankles on the day prior to the infusion of albumin. This time, no albumin was preinfused. Total serum protein was $4.8 \mathrm{Gm}$. per cent (biuret method); hemoglobin, 90 per cent $(14.4 \mathrm{Gm}$. per $100 \mathrm{ml}$.) ; and hematocrit, 40 per cent.

On July 23, 1958, $68.5 \mu$ c. of $\mathrm{I}^{131}$-albumin (about $50 \mathrm{mg}$.) was added to $148 \mathrm{Gm}$. of Behring-albumin (Lot No. $1321 \mathrm{n}$ ) in $740 \mathrm{ml}$. of a solution containing 0.5 per cent $\mathrm{NaCl}$ and 0.4 per cent $\mathrm{NaHCO}_{3}$ in water. Two hundred fifty $\mathrm{ml}$. of this mixture was made up to $1,000 \mathrm{ml}$. with 0.9 per cent saline solution; the rest was diluted with 5 per cent glucose solution to a volume of $2,000 \mathrm{ml}$. This total of $3,000 \mathrm{ml}$. of 5 per cent albumin solution was infused into the fasting subject on the same day between $11: 30$ a.m. and 8:20 p.m. At 6 p.m. she received a light supper which she vomited two minutes after the infusion was over. Otherwise, the patient was doing well.

During the following observation period of 52 days, a total of about $300 \mathrm{ml}$. of blood was taken. In the serum and plasma samples, radioactivity was measured in the same way as in the 1957 experiment. The albumin content was determined immunologically and by paper electrophoresis.

The half-lives of both labeled and unlabeled human serum albumin were essentially identical, a result which Dr. McFarlane and his co-workers had anticipated from previous experience with labeled albumins and from the fact that the labeled molecules were mixed in this experiment with the unlabeled ones prior to the infusion. The specific radioactivities of the albumin did not change sig- nificantly during the observation period of seven and one-half weeks (20). As on previous occasions, only an extremely small apparent disappearance took place during the first five days. again probably because the albumin was infused rather than injected with a corresponding uncertainty in the significance of the origin.

The results (Figure 8) support the following conclusions: 1) The subject's protein metabolism was unable to discriminate between unlabeled albumin and the same albumin labeled by Dr. McFarlane's (21) procedure. Therefore, half-life values determined by use of this labeled albumin have some metabolic significance.

2) The $I^{131}$-albumin used in February, 1954 , was probably also undenatured because it behaved in a normal fashion in the control subject; in addition, there was only a relatively slight initial fall in plasma radioactivity during the first six to eight days following the injection.

3) The $I^{131}$-albumin used in May, 1957. was probably abnormal $(20,22)$ since there was an unusually large initial fall in plasma radioactivity and the half-life was significantly shorter than that of the unlabeled protein.

\section{DISCLSSION}

Half-life values of 25.6 to 65 days for $\mathrm{S}^{35}$ - or $\mathrm{C}^{14}$-labeled human serum albumins were found by Niklas and Maurer (23), Niklas and Poliwoda (24), Armstrong and co-workers $(25,26), \mathrm{Ma}-$ souredis and Beeckmans (27), and Margen and Tarver (28). Margen and Tarver (28) have observed that the metabolic half-life of the $\mathrm{I}^{131}$-label 


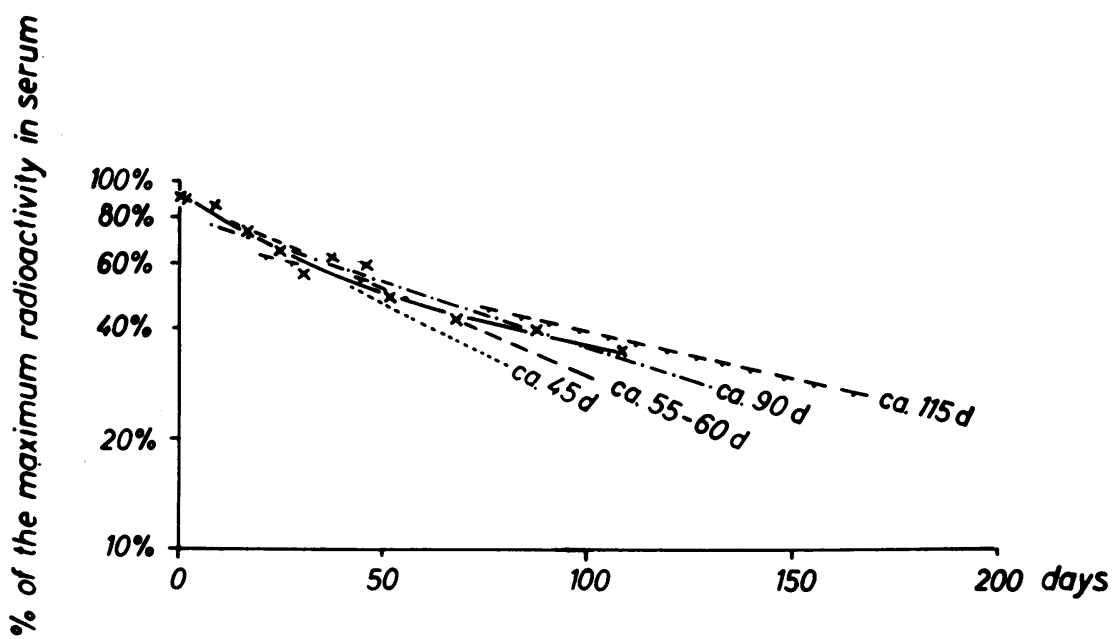

Fig. 9. Different Possibilities of Evaluating the 1958 Paper Electrophoretic Half-Life Curve Within a Preliminary Observation Period of 109 Days

is considerably lower than that of $\mathrm{C}^{14}$ or $\mathrm{S}^{35}$ labels in the same animals or subjects. The half-life curves in our second experiment obtained with $\mathrm{I}^{131}$-labeled and unlabeled human albumin could conform in principle with some of these authors' findings. On the other hand, the results of our first and third experiments do not.

More recently McFarlane (14) and co-workers have found no difference in half-lives when using mixtures of $\mathrm{I}^{131}$ - and $\mathrm{C}^{14}$-labeled serum proteins in animals. In view of the lack of agreement in our first two experiments on the analbuminemic subject, we still had some doubts as to the reliability of breakdown rates obtained by the use of iodinated proteins in general (29). Therefore, we undertook a crucial third experiment in co-operation with Dr. McFarlane and his co-workers. In our opinion, it has now been shown that, provided sufficient care is taken in the preparation of the labeled human albumin, the use of the ${ }^{131}$-label is justified for metabolic studies. As we have shown in this paper, both the initial disappearance rate and half-life of the labeled albumin are identical with the values obtained by use of the nonlabeled protein.

Miller and Bale (30) have shown conclusively that serum albumin is synthesized and metabolized in the liver. As is evident from our experiments, both synthesis and breakdown of albumin seem to be linked together in some way.

Since the catabolism of albumin is only slowed, but not blocked, in this case of analbuminemia, there must exist several ways by which albumin can be metabolized by the liver in general:a) a process highly specific for albumin, which apparently fails to work in this subject; $b$ ) a nonspecific catabolism of albumin which has retained its efficiency; c) a process associated with the integrity of albumin molecules. As we have shown in our second experiment, denatured albumin molecules disappear more rapidly from the blood stream than intact molecules; $d$ ) since the analbuminemic subject does not exhibit symptoms of myxedema or other severe endocrinological disorders, the influence of the thyroid $(31,20)$ and other hormones on the catabolism of proteins may be disregarded in the interpretation of the half-life values in this case.

In any event, the half-life of albumin is definitely much longer in this case of analbuminemia than in normals. However, we have found a considerable latitude in drawing the half-life curves of infused albumin (cf. Figures 2, 4 and 9); therefore, we are unable to determine the half-life in this subject more exactly than within a range of between 40 and 110 days (Figures 2, 7 and 9), apparently depending only on the time period during which the $\mathrm{I}^{131}$-albumin content of plasma can be measured exactly. Similarly, deductions regarding extravascular space cannot be made with any accuracy if substantial amounts of albumin are infused over a significant time interval. This arises mainly from unpredictable shifts of fluid and al- 
bumin which obscure the true origin ("100 per cent") in the graphs.

\section{SUM MARY}

1) The half-life values of $I^{131}$-albumin and nonradioactive human serum albumin were compared in a case of analbuminemia.

2) In one experiment using a commercially available $\mathrm{I}^{131}$-albumin, the half-life values and initial disappearance rates differed considerably.

3) In two other experiments, one of them using an albumin which had been labeled for us by Dr. A. S. McFarlane, both the half-lives and initial disappearance rates of labeled and unlabeled albumin were identical.

4) Some implications of these findings are discussed.

\section{ACKNOWLEDGMENTS}

The authors are indebted to Drs. A. S. McFarlane, C. M. E. Matthews and T. Freeman for generously providing us with iodinated $\mathrm{I}^{131}$-albumin and for a critical review of the manuscript. We also wish to thank Mrs. I. Tappe for drawing the diagrams.

\section{REFERENCES}

1. Bennhold, H., Peters, H., and Roth, E. Ueber einen Fall von kompletter Analbuminaemie ohne wesentliche klinische Krankheitszeichen. Verh. dtsch. Ges. inn. Med. 1954, 60, 630.

2. Bennhold, H. Die Bedeutung der Bluteiweisskörper fuer den Wasserhaushalt. Regensburg Jb. ärztl. Fortbild. 1954/55, No. IV, 72.

3. Bennhold, H. Kongenitale Defektdysproteinämien. Verh. dtsch. Ges. inn. Med. 1956, 62, 657.

4. Ott, H. Das Blutserum bei Analbuminämie. Weitere Untersuchungen über die Serumfraktionen, das Farbstoffbindungsvermögen und den kolloidosmotischen Druck. Z. ges. exp. Med. 1957, 128, 340.

5. Bennhold, H., and Scheurlen, G. In preparation.

6. Banks, H. H., Seligman, A. M., and Fine, J. The effect of hyaluronidase on the absorption of parenterally administered radioactive plasma proteins in the dog. J. clin. Invest. 1949, 28, 548.

7. Heidelberger, M., and Kendall, F. E. The precipitin reaction between type III pneumococcus polysaccharide and homologous antibody. III. A quantitative study and a theory of the reaction mechanism. J. exp. Med. 1935, 61, 563.

8. Peters, J. P., and Van Slyke, D. D. Quantitative Clinical Chemistry. Vol. II, Methods. Baltimore, Williams \& Wilkins, 1932. [Cit. by Lempp, R. Über die Fehlerbreite der van Slyke' schen Kupfersulfatmethode zur quantitativen Serumeiweissbestimmung im Vergleich mit anderen Verfahren. Dissertation, Tübingen, 1950.]
9. Bennhold, H. Ueber die Ausscheidung intravenoes einverleibten Kongorotes bei den verschiedensten Erkrankungen, insbesondere bei Amyloidosis. Dtsch. Arch. klin. Med. 1923, 143, 32.

10. Scheurlen, P. G. Untersuchungen ueber die Regulation der Serumeiweisskoerper. Medizinische 1958, No. 33/34, 1246.

11. Bennhold, H., Ott, H., and Scheurlen, P. G. Beitraege zur Frage der genbedingten Bluteiweißstörungen. Verh. dtsch. Ges. inn. Med. 1958, 64, 279.

12. Lohss, F., and Kallee, E. Spurennachweis von Albumin durch Analyse von Antigen-Antikoerperpraecipitaten. Clin. chim. Acta 1959, 4, 127.

13. Freeman, T., Matthews, C. M. E., McFarlane, A. S., Bennhold, H., and Kallee, E. ${ }^{131} \mathrm{I}$-albumin in an analbuminemic subject. Nature (Lond.) 1959. In press.

14. McFarlane, A. S. Use of labeled plasma proteins in the study of nutritional problems (a review). Progr. Biophysics 1957, 7, 115-163.

15. Matthews, C. M. E. The theory of tracer experiments with ${ }^{131} \mathrm{I}$-labelled plasma proteins. Phys. in Med. Biol. 1957, 2, 36.

16. Berson, S. A., Yalow, R. S., Schreiber, S. S., and Post, J. Tracer experiments with $\mathrm{I}^{131}$ labeled human serum albumin: Distribution and degradation studies. J. clin. Invest. 1953, 32, 746.

17. Storaasli, J. P., Krieger, H., Friedell, H. L., and Holden, W .D. The use of radioactive iodinated plasma protein in the study of blood volume. Surg. Gynec. Obstet. 1950, 91, 458.

18. Bennhold, H., Kallee, E., and Roth, E. Autoradiographisches Verfahren zur qualitativen papierelektrophoretischen Auftrennung kleiner und kleinster Eiweissmengen. Z. Naturforschg. 1952, 7b, 661.

19. Scheurlen, P. G. Beitrag zur Auswertung der Papierelektrophoresestreifen mit Integrationsgeräten. Klin. Wschr. 1957, 35, 485.

20. Iber, F. L., Nassau, K., Plough, I. C., Berger, F. M., Meroney, W. H., and Fremont-Smith, K. The use of radioiodinated albumin in metabolic studies. The effects of the level of dietary protein and L-triiodothyronine on the catabolism of radioiodinated human serum albumin. J. clin. Invest. 1958, 37, 1442.

21. McFarlane, A. S. Labelling of plasma proteins with radioactive iodine. Biochem. J. 1956, 62, 135.

22. Steinfeld, J. L., Greene, F. E., Tabern, D. L., Paton, R. R., and Flick, A. L. Degradation of iodinated human serum albumin prepared by various procedures. J. Lab. clin. Med. 1958, 51, 756.

23. Niklas, A., and Maurer, W. Messung der Neubildungs- und Abbaugeschwindigkeit einzelner Serumeiweissfraktionen nach Gabe von $\mathrm{S}^{35}$-Methionin. Verh. dtsch. Ges. inn. Med. 1953, 59, 319.

24. Niklas, A., and Poliwoda, H. Zur Frage der biologischen Halbwertszeit menschlicher Albumine und Globuline. Biochem. Z. 1954, 326, 97. 
25. Armstrong, S. H., Jr., McLeod, K., Wolter, G., and Kukral, J. The persistence in the blood of the radioactive label of albumins, gamma globulins, globulins of intermediate mobility studied with $S^{35}$ and paper electrophoresis: Methods and preliminary results. J. Lab. clin. Med. 1954, 43, 918.

26. Armstrong, S. H., Jr., Bronsky, D., and Hershman, $\mathrm{J}$. The persistence in the blood of the radioactive label of albumins, gamma globulins and globulins of intermediate mobility. III. Comparison of dieaway plots following oral and intravenous administration of the $\mathrm{S}^{25}$ label to the same subjects. J. Lab. clin. Med. 1955, 46, 857.

27. Masouredis, S. P., and Beeckmans, M. L. Comparative behavior of $\mathrm{I}^{181}$ and $\mathrm{C}^{14}$ labelled albumin in plasma of man. Proc. Soc. exp. Biol. (N. Y.) 1955, 89, 398.
28. Margen, S., and Tarver, $H$. The deiodination of proteins labeled with $\mathrm{I}^{131}$. Ann. N. Y. Acad. Sci. 1957, 70, 49.

29. Freeman, T., and Matthews, C. M. E. Analysis of the behaviour of $\mathrm{I}^{131}$-albumin in nephrotic patients (with discussion remarks by Kallee, E.) in Radioaktive Isotope in Klinik und Forschung. Vienna, Verlag Urban \& Schwarzenberg, 1958, vol. III, 306.

30. Miller, L. L., and Bale, W. F. Synthesis of all plasma protein fractions except gamma globulins by the liver. J. exp. Med. 1954, 99, 125.

31. D'Addabbo, A., and Kallee, E. ${ }^{181} \mathrm{~J}$-Serumproteine und Schilddrüse. Z. Naturforschg. 1959, 14b, 240.

32. Bennhold, H. Ueber die Vehikelfunktion der Serumeiweisskoerper. Ergebn. inn. Med. Kinderheilk. 1932, 42, 273. 